\title{
Factor IX Activity Measurement
}

National Cancer Institute

\section{Source}

National Cancer Institute. Factor IX Activity Measurement. NCI Thesaurus. Code C103395.

The determination of the amount of the biological activity of factor IX in a sample. 